\title{
Lansky Performance Status 60
}

National Cancer Institute

\section{Source}

National Cancer Institute. Lansky Performance Status 60. NCI Thesaurus. Code C69422.

Up and around, but minimal active play; keeps busy with quieter activities. 